\title{
Pengembangan Media Pembelajaran Interaktif Pada Materi Momentum dan Impuls Kelas X SMA
}

\author{
Haeirani Irawan ${ }^{*}$, Muhammad Taufik¹, Syahrial Ayub ${ }^{1}$ \\ ${ }^{1}$ Program Studi Pendidikan Fisika, FKIP Universitas Mataram, Mataram, Indonesia.
}

DOI: https://doi.org/10.29303/goescienceedu.v2i1.87

\section{Article Info}

Received : 5 Januari 2021

Revised : 8 Juni 2021

Accepted: 30 Juni 2021

\begin{abstract}
Abstrak: Penelitian ini bertujuan untuk mengembangkan media pembelajaran interaktif pada materi momentum dan impuls kelas X SMA dan mengetahui kelayakan media pembelajaran interaktif. Jenis penelitian yang digunakan adalah penelitian dan pengembangan yang dikembangkan oleh Thiagarajan yaitu 4D (Define, Design, Develop, Disseminate). Hasil penelitian berupa produk dari media pembelajaran interaktif berbasis komputer dengan kategori kelayakan berdasarkan ahli media sebesar 85\% (sangat baik) dan berdasarkan ahli materi sebesar $81 \%$ (sangat baik). Uji coba secara terbatas tidak dilakukan karena keterbatasan keaadaan dan waktu. Disimpulkan bahwa penelitan ini menghasilkan Produk berupa software media pembelajaran yang memiliki kategori kelayakan sangat baik.
\end{abstract}

Kata kunci: pengembangan; media pembelajaran interaktif; momentum dan impuls

Abstract: This research aims to develop interactive learning media on momentum materials and impulses of grade $X$ senior high school and to know the feasibility of interactive learning media. The type of research used is research and development developed by Thiagarajan is $4 \mathrm{D}$ (Define, Design, Develop, Disseminate). The results of the products from computer-based interactive learning media with a feasibility category based on media experts of $85 \%$ (excellent) and based on material experts of $81 \%$ (excellent). Limited trials are not conducted due to limitations of civility and time. It is concluded that this research produces products in the form of learning media software that has an excellent feasibility category.

Key words: development; Interactive Learning Media; Momentum and Impulse

\section{Pendahuluan}

Pendidikan meliputi banyak ilmu pengetahuan termasuk diantaranya adalah sains. Fisika merupakan salah satu bagian dari sains. Fisika membutuhkan suatu praktik untuk lebih memahami konsep-konsep yang ada. Sifat Fisika yang abstrak membuat banyak kesalahpahaman dalam mendefinisikan pelajaran fisika. Dewasa ini fisika dikenal sebagai pelajaran yang penuh dengan rumus-rumus sehingga banyak peserta didik mengasumsikan bahwa fisika sulit. Namun, tidak dapat dipungkiri bahwa pembelajaran fisika disekolah kurang menarik minat peserta didik ditambah dengan model pembelajaran yang diterapkan dengan metode ceramah saja. Pendapat di atas sejalan dengan Astra (2012) menyatakan bahwa pelajaran dengan metode ceramah merupakan pelajaran yang sulit dan tidak disenangi siswa.

Tuntutan kurikulum 2013 beberapa diantarannya menciptakan pembelajaran yang menyenangkan, menyediakan pengalaman secara langsung kepada peserta didik. Usaha yang dilakukan dalam rangka kearah tersebut, diperlukan metode yang berbeda dalam pembelajaran. Upaya untuk mengatasinya yaitu dengan meningkatkan proses pendidikan agar pembelajaran menyenangkan dan dapat memberikan pengalaman secara langsung kepada peserta didik. Salah satunya yaitu dibutuhkan 
media pembelajaran yang sesuai saat proses pembelajaran. Pembelajaran yang diinginkan untuk meningkatkan kualitas pendidikan yaitu pembelajaran yang menekankan pada interaksi dua arah antara media yang digunakan dengan pengguna media, maka peserta didik tidak hanya mengamati dan menghafal pembelajaran yang ada di media atau yang dijelaskan oleh guru saja. Sehingga aktifitas peserta didik bukan hanya mendengarkan namun merespon apa yang diminta pada media tersebut. Interaktif memberikan kesan apa yang dapat dilakukan siswa terhadap media (Handhika, 2012). Widyawati \& Prodjosantoso, (2015), menyatakan bahwa rendahnya nilai Fisika yang diperoleh siswa disebabkan karena bahan ajar yang diberikan mempunyai tampilan yang kurang menarik.

Di era teknologi informasi yang berkembang seperti saat ini sangat mendukung jika media pembelajaran yang digunakan sebagai alat pendukung proses pembelajaran berbasis komputer. Keunggulan penggunaan media komputer yaitu peserta didik dapat belajar dan mengulang pelajaran dimana saja seperti di rumah, di sekolah atau dimana saja. Perkembangan teknologi komputer menghadirkan inovasi dalam proses pembelajaran sains, khusus pada fisika (Gunawan, 2017). Menurut Widada dalam (Rahmawati, 2019) salah satu media pembelajaran yang menarik perhatian bagi siswa di era teknologi informasi ini adalah multimedia. Menggunakan media Multimedia Pembelajaran dapat meningkatkan hasil belajar siswa disebabkan karena Multimedia Pembelajaran memberikan kemudahan kepada guru dan siswa untuk memahami materi yang diberikan, dibandingkan dengan hanya menggunakan buku saja dalam proses pembelajaran (Rofiq, 2019).

Berdasarkan Hasil observasi yang dilakukan oleh peneliti di SMAN 1 Lingsar selama melaksanakan Program Pengalaman Lapangan (PPL) Tahun Pelajaran 2019/ 2020 disimpulkan bahwa permasalahan yang terjadi di lapangan adalah guru mengajar dengan metode ceramah, belum menggunakan media pembelajaran yang menarik. Praktikum di sekolah tersebut jarang dilakukan, karena laboratorium fisika yang seharusnya digunakan untuk praktikum, dialih fungsikan sebagai ruang. Penggunaan media hanya terpaku pada buku paket dan LKS (Lembar Kerja Siswa) yang sifatnya satu arah. Tersediannya ruang komputer, LCD (Liquid Crystal Display) kurang dimanfaatkan secara optimal sebagai media pembelajaran. Penggunaan komputer hanya digunakan pada pelaksanakan Ujian Nasional Berbasis Komputer (UNBK). Hal ini yang menjadi alasan peneliti untuk mengembangkan media pembelajaran interaktif berbasis komputer.

Softwere yang digunakan peneliti untuk mengembangkan media pembelajaran interaktif adalah
Macromedia Flash Pro 8. Flash merupakan perangkat lunak popular berbasis vector yang digunakan salah satunya untuk membuat animasi interaktif. Macromedia Flash merupakan perangkat lunak yang menggabungkan teks, gambar, video, animasi dan suara sehingga dapat memberikan bentuk penyajian secara visual yang menarik. Selain menggunakan Flash peneliti juga menggunakan beberapa perangkat lunak lainnya sebagai pembantu dalam proses pengembangan media seperti Photoshop CS6, Power point dan program lainnya. Materi yang dipilih peneliti adalah momentum dan impuls KD 3.10.

Media yang dikembangkan peneliti telah dilengkapi animasi yang memberikan pengalaman langsung kepada peserta didik seperti layaknya sedang menyaksikan kejadian langsung di dalam kelas tanpa harus melakukan praktikum secara langsung. Sejalan dengan penelitian Putri (2014) mengatakan bahwa penggunaan media pembelajaran interaktif lebih baik dalam meningkatkan pengetahuan siswa dalam pembelajaran fisika daripada penggunaan media powerpoint. Penelitian serupa juga pernah dilakukan oleh Tarigan dan Sahat (2015), media pembelajaran yang dikembangkan pada penelitian tersebut layak untuk digunakan sebagai media pembelajaran Ekonomi, karena memiliki nilai rata-rata kelayakan yang lebih tinggi.

Berdasarkan permasalahan di atas penelitian ini bertujuan mengembangkan media pembelajaran interaktif pada materi momentum dan impuls kelas $X$ SMA dan mengetahui kelayakan hasil pengembangan media pembelajaran interaktif pada materi momentum dan impuls kelas X SMA.

\section{Metode}

Jenis penelitian ini adalah penelitian dan pengembangan model 4D (Define, Design, Develop, and Disseminate) yang dikembanngkan oleh Thiagarajan. Penelitian dan pengembangan adalah metode penelitian yang bertujuan untuk mengembangkan media pembelajaran dan menguji keefektifan produk tersebut (Sugiyono, 2018). Namun karena keterbatasan waktu dan keadaan tahapan pengembangan media yang digunakan peneliti hanya sampai pada $\mathrm{D}$ yang ketiga yaitu tahap develop pada uji validitas oleh ahli. Tahap pengembangann yang dilakukan peneliti adalah:

1) Define (pendefinisian)

Tahap define bertujuan untuk menetapkan dan mendefinisikan syarat-syarat pembelajaran. Tahap ini terdiri dari Analisis awal, Analisis kemampuan peserta didik, Analisis tugas, Analisis konsep dan Spesifikasi tujuan penggunaan produk.

2) Tahap Design (perancangan) 
Tahap ini bertujuan untuk menyiapkan struktur perangkat pembelajaran yang akan dikembangkan. Tahap ini terdiri dari a) Pemilihan media pembelajaran, pemilihan media dilakukan guna memfasilitasi pembelajaran secara optimal agar tujuan dari pembelajaran dan pembuatan media tercapai. Pemilihan media disesuaikan dengan kebutuhan, analisis konsep, analisis tugas yang telah dibuat. Media dibuat menggunakan softwere macromedia flash pro 8, dikemas secara menarik menjadi media pembelajaran interaktif. dan b) Pembuatan desain awal media pembelajaran, desain awal adalah pedoman penting dalam mempresentasikan media yang tepat dalam kerangka yang sesuai. Pada tahap ini media pembelajaran dirancang dengan membuat diagram alir (flowchart) menggambarkan struktur dari media pembelajaran. Sedangkan visualisasi media pembelajaran dibuat dalam bentuk storyboard.

3) Tahap Develop (pengembangan)

Tujuan pada tahap ini adalah untuk menghasilkan perangkat pembelajaran yang telah direvisi berdasarkan masukan dari pakar ahli/ praktisi. tahapan ini meliputi validasi perangkat media pembelajaran oleh ahli media untuk mengetahui kevalidan media pembelajaran dari segi kualitas tampilan media. Sedangkan untuk megetahui kevalidan media pembelajaran dari segi materi di lakukan oleh ahli materi. Validasi media pembelajaran dilakukan oleh enam orang ahli media dan enam orang ahli materi. Termasuk didalamnya Revisi (perbaikan) dilakukan sesuai dengan hasil validasi dari dosen ahli media, materi. Revisi ini menciptakan produk yang memenuhi kriteria kelayakan media pembelajaran.

Pengumpulan data pada penelitian ini dilakukan dengan memberikan instrumen penilaian, menggunakan instrument berupa lembar validasi ahli media dan ahli materi untuk mengetahui kelayakan media pembelajaran Data yang telah dikumpulkan menggunakan instrument penilaian selanjutnya dianalisis secara kuanlitatif dan kuantitatif.

Hasil analisis data kualitatif didapatkan berdasarkan kritik, masukan dan saran dari validator. Hasil analisis ini kemudia digunakan sebagai bahan untuk merevisi media pembelajaran interaktif. Analisis data kuantitatif didapatkan dari skor yang diberikan pada lembar validasi oleh ahli media dan materi. Kriteria pemberian skor yaitu 4 (Sangat Baik), 3 (Baik), 2 (Cukup Baik) dan 1 (Sangat Kurang Baik). Data penilaian validator ahli materi dan ahli media akan digunakan untuk mengetahui kualitas dari rancangan produk media pembelajaran interaktif ini. Dosen validator memberikan penilaian untuk direvisi sampai produk dinilai layak untuk diuji cobakan ke peserta didik.. Skor kemudian diolah menggunakan rumus persentase sebagai berikut

$$
\text { penilaian }=\frac{\sum \text { Skor yang didapatkan }}{\sum \text { Skor ideal }} \times 100 \%
$$

Setelah mendapatkan hasil penilaian, dengan menggunakan tabel kecenderungan data untuk menentukan kategori penilaian. Kategori penilaian ada pada tabel

Tabel 1. Kriteria Penilaian Media Pembelajaran

\begin{tabular}{lll}
\hline Nilai & Kriteria & Persentase \\
\hline 1 & Sangat baik & $81 \% \leq X \leq 100 \%$ \\
2 & Baik & $61 \% \leq X<80 \%$ \\
3 & Sedang & $41 \% \leq X<60 \%$ \\
4 & Kurang baik & $21 \% \leq X<40 \%$ \\
5 & Sangat kurang baik & $0 \% \leq X<20 \%$ \\
\hline X: Skor empiris & (Purwanto, 2009)
\end{tabular}

\section{Hasil Dan Pembahasan}

Hasil penelitian dan pengembangan ini adalah produk berupa media pembelajaran interaktif pada materi momentum dan impuls kelas X SMA berbasis komputer. Softwere yang digunakan untuk mengembangkan media adalah Macromedia Flash Professional 8. Tahap-tahapan yang dilakukan pada penelitian dan pengembangan ini yaitu 1)Define (pendefinisian), 2)Design (perancangan) dan 3)Develop (pengembangan).

\section{1) Design (pendefinisian)}

a. Analisis awal, bertujuan untuk menetapkan masalah dasar yang dihadapi oleh peserta didik. Analisis awal yang dilakukan peneliti bertempat di SMAN 1 Lingsar. Berdasarkan analisis awal menunjukan bahwa peserta cenderung tidak menyukai pelajaran fisika karena sulit dipahami dan banyak rumus-rumus, metode pelajaran yang monoton, kurangnya variasi/ penggunaan media pembelajaran.

b. Analisi kebutuhan peserta didik, bertujuan untuk mengetahui kebutuhan peserta didik dalam menunjang pembelajaran di sekolah. Hasil identifikasi didapatkan bahwa proses pembelajaran belum didampingi percobaan-percobaan, ketersedian media atau alat percobaan yang tidak mendukung menjadi salah satu faktor.

c. Analisis tugas, bertujuan untuk menentukan isi materi pelajaran yang akan dicantumkan dan dicapai sesuai Kompetensi Inti (KI), Kompetensi Dasar (KD) dan indikator yang digunakan.

d. Analisis konsep, meliputi konsep- konsep materi momentum dan impuls yang akan dicantumkan pada media pembelajaran sesuai dengan analisis tugas yang dilakukan peneliti. Berikut hasil analisis konsep 


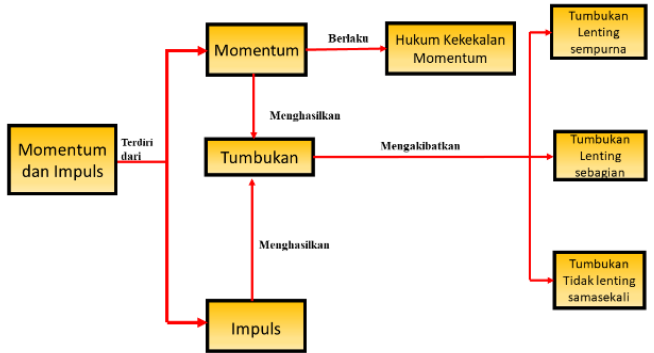

Gambar 1. peta konsep materi momentum dan impuls

e. Perumusan tujuan penggunaan produk. Berdasarkan hasil analisis awal, analisis kebutuhan peserta didik, analisis tugas dan analisis konsep yang telah dilakukan peneliti. Tujuan penggunaan produk adalah untuk menyediakan media pembelajaran interaktif pada materi momentum dan impuls kelas X SMA yang menarik dan inovatif

\section{2) Design (perancangan)}

a. Pemilihan media pembelajaran

Pemilihan media pembelajaran telah disesuaikan dengan karakteristik peserta didik pada tahap pendefinisian. Langkah pertama pada pemilihan media pembelajaran ini adalah pembuatan baground, mendisign tombol yang akan digunakan, memasukan materi yang akan ditampilkan pada media pembelajaran, membuat animasi menggunakan macromedia pro 8 sesuai dengan materi, memilih sound yang tepat sebagai efek untuk animasi dan tombol agar media yang dihasilkan menarik.

b. Pembuatan desain awal media pembelajaran

Desain awal media pembelajaran di buat untuk membuat visualisasi media pembelajaran berdasarkan flowchart dan storyboard yang telah disusun peneliti. Berikut gambar hasil visualisasi media pembelajaran yang peneliti kembangkan.

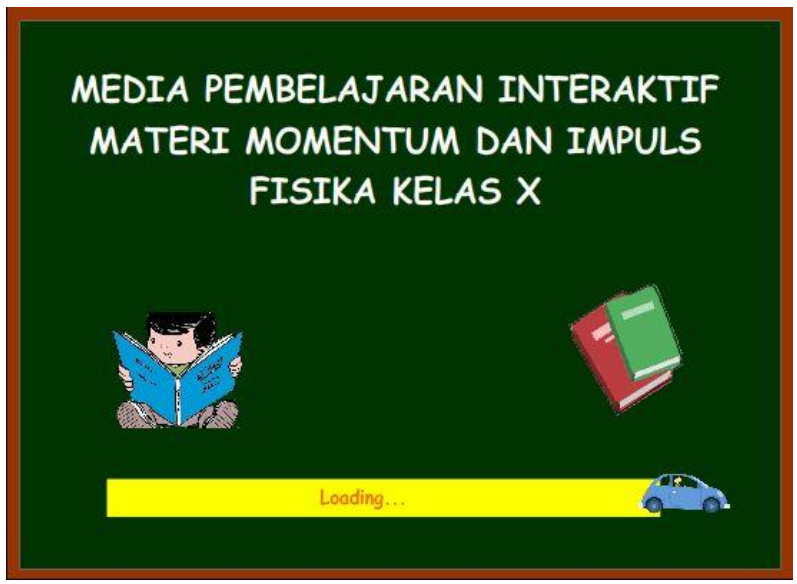

Gambar 2. Tampilan awal media pembelajaran interaktif.

Gambar 2 merupakan halaman awal/ judul untuk masuk ke media pembelajaran. Halaman menu utama terdiri dari menu-menu yang dapat dipilih oleh peserta didik sesuai dengan option yang diinginkan seperti gambar 3 .

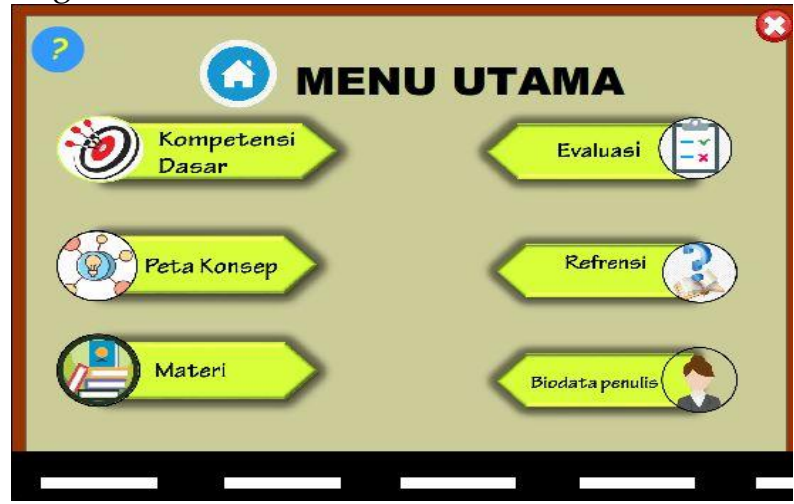

Gambar 3. Halaman menu utama.

Kompetensi dasar dan indikator yang akan dicapai setelah menggunakan materi terdapat pada gambar 4. tombol menu jika ingin kembali ke menu utama dan keluar jika ingin keluar dari media pembeajaran juga disediakan.

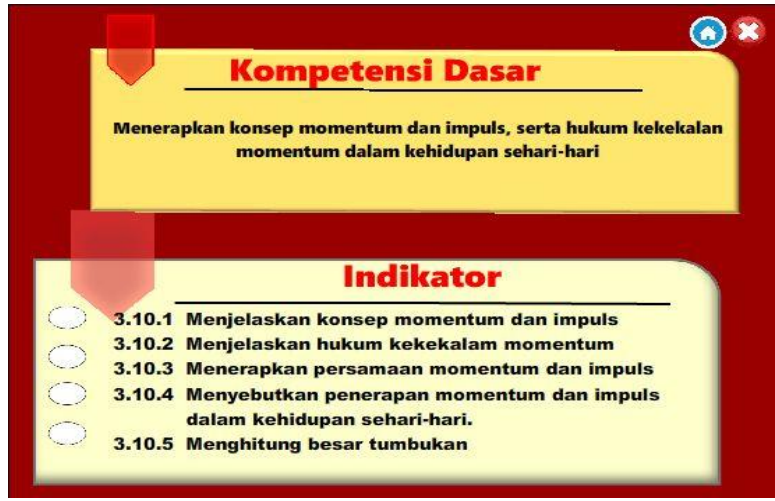

Gambar 4. Halaman KD dan Indikator

Halaman selanjutnya adalah halaman materi yang akan dipelajari oleh peserta didik. Menu materi terdiri dari tiga sub materi yaitu momentum, impuls dan tumbukan. Isi halaman materi bisa dilihat pada gambar 5 .

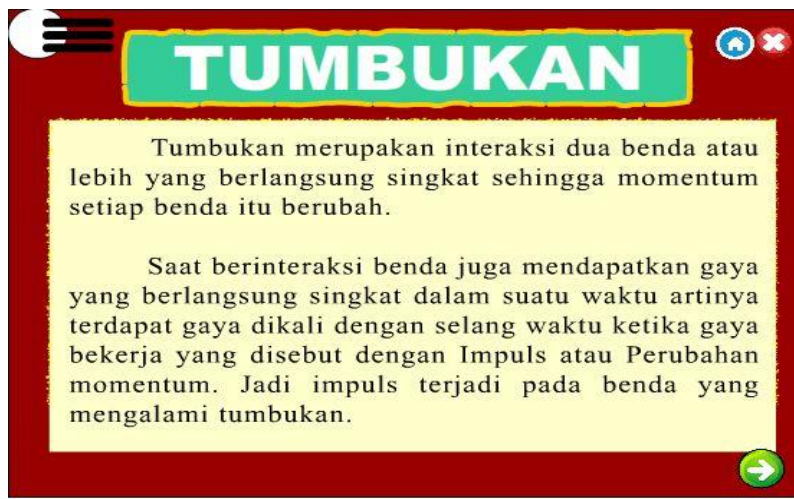

Gambar 5. Halaman materi

Halaman evaluasi terdiri dari soal-soal latihan. Soal latihan terdiri dari lima soal mengenai materi momentum, impuls dan tumbukan. Peserta didik dapat 
langsung melihat skor yang diperoleh setelah mengerjakan latihan.

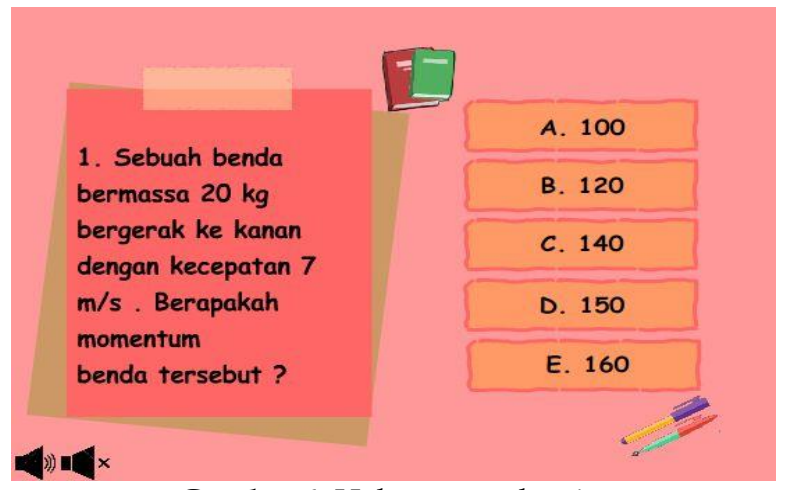

Gambar 6. Halaman evaluasi

\section{3) Develop (pengembangan)}

Tahap pengembangan yang dilakukan peneliti terdiri dari dua langkah yaitu validasi ahli dan praktisi dan revisi hasil validasi dari ahli dan praktisi. Tahap validasi media dilakukan bertujuan untuk mengetahui kelayakan media pembelajaran.

Untuk mengetahui kualitas media pembelajaran, peneliti menggunakan dua validator yaitu validator ahli media dan ahli materi. Hasil validator didapatkan dua data yaitu data kualitatif dan data kuantitatif. Berdasarkan data kualitatif peneliti diberikan saran, komentar dan masukan sebagai bahan revisi produk. Data kuantitatif penelitian ini diperoleh dari hasil penilaian validator ahli dan validator praktisi yang diberikan pada angket penilaian dengan skala penilaian 1 sampai dengan 4. Hasil penilaian dapat dilihat pada tabel 2 dan tabel 3 di bawah ini

Tabel 2. Hasil Analisis Penilaian Media Pembelajaran Interaktif dari Validator Ahli Media

\begin{tabular}{llll}
\hline No & Aspek & $\overline{\mathbf{x}}$ per Aspek & Kategori \\
\hline 1 & Umum & $81 \%$ & Sangat Baik \\
2 & Tampilan & $85 \%$ & Sangat Baik \\
3 & Pemograman & $89 \%$ & Sangat Baik \\
Rata-rata keseluruhan & $85 \%$ & Sangat Baik \\
\hline
\end{tabular}

Tabel 3. Hasil Analisis Penilaian Media Pembelajaran Interaktif dari Validator Ahli Materi

\begin{tabular}{llll}
\hline No & Aspek & $\overline{\mathbf{x}}$ per Aspek & Kategori \\
\hline 1 & Kualitas Materi & $82 \%$ & Sangat Baik \\
2 & Kualitas Bahasan & $86 \%$ & Sangat Baik \\
3 & Interaksi & $77 \%$ & Sangat Baik \\
4 & Kualitas Soal Latihan & $81 \%$ & Sangat Baik \\
Rata-rata keseluruhan & $81 \%$ & Sangat Baik \\
\hline
\end{tabular}

Berdasarkan penilaian kelayakan media pembelajaran menggunakan angket validasi dari ahli media dan ahli materi maka dapat disimpulkan bahwa media pembelajaran layak digunakan dengan kategori sangat baik dengan nilai rata-rata $85 \%$ dari segi media dan $81 \%$ dengan kategori sangat baik dari segi materi media pembelajaran interaktif..

\section{Kesimpulan}

Berdasarkan rumusan masalah, tujuan pembelajaran, hasil penelitian dan pembahasan yang telah dilakukan, disimpulkan bahwa penelitian dan pengembangan ini menghasilkan produk berupa media pembelajaran interaktif. Produk yang dihasilkan berupa software media pembelajaran interaktif pada materi momentum dan impuls kelas X SMA. Kualitas produk multimedia pembelajara interaktif ini memiliki kategori kelayakan sangat baik.

\section{Daftar Pustaka}

Astra, I.M. (2012). Aplikasi Mobile Learning Fisika dengan Menggunakan Adope Flash sebagai Media Pembelajaran. Jurnal Pendidikan dan Kebudayaan, 18(2), 56-65.

Gunawan, Harjono, A., Sutrio. (2017). Multimedia Interaktif dalam Pembelajaran Konsep Listrik bagi Calon Guru. Jurnal Pendidikan Fisika dan Teknologi. I (1). 9-14.

Handhika, J. (2012). Efektifitas Media Pembelajaran IM3 ditinjau dari Motivasi Belajar. Jurnal Pendidikian IPA Indonesia (JPII) 1(2), 109-114.

Putri, I. P., \& Sibuea, A. M. (2014). Pengembangan Media Pembelajaran Interaktif Pada Mata Pelajaran Fisika. Jurnal Teknologi Informasi $\mathcal{E}$ Komunikasi dalam Pendidikan, 1(2).

Rahmawati, A. S., \& Dewi, R. P. (2019). Penggunaan Multimedia Interaktif (MMI) Sebagai Media Pembelajaran Dalam Meningkatkan Prestasi Belajar

Rofiq, A., Mahadewi, L. P. P., \& Parmiti, D. P. (2019). Pengembangan Multimedia Pembelajaran Interaktif Pada Mata Pelajaran Ips Terpadu. Journal of Education Technology, 3(3), 126-133. Fisika. Jurnal Pendidikan Fisika dan Teknologi, 5(1), 50-58.

Sugiyono. (2018). Metode Penelitian Pendidikan Pendekatan Kuantitatif Kualitatif dan RED. Bandung: Alfabeta.

Tarigan, D., \& Siagian, S. (2015). Pengembangan Media Pembelajaran Interaktif Pada Pembelajaran Ekonomi. Jurnal Teknologi Informasi \& Komunikasi dalam Pendidikan, 2(2).

Widyawati, A., \& Prodjosantoso, A. K. (2015). Pengembangan media komik IPA untuk meningkatkan motivasi belajar dan karakter peserta didik SMP. Jurnal Inovasi Pendidikan IPA, 1(1), 24-35. 